\title{
EFL Teachers' Reflective Teaching, Use of Motivational Strategies, and Their Sense of Efficacy
}

\author{
Mania Nosratinia \\ Islamic Azad University at Central Tehran, Iran \\ Zahra Moradi \\ Islamic Azad University at Central Tehran, Iran
}

\begin{abstract}
The present study aimed at systematically investigating the relationship among EFL teachers' Reflective Teaching (RT), Use of Motivational Strategies (UMS), and Sense of Efficacy (SE). The participants of the study were 194 male and female EFL teachers, between 20 to 30 years of age $\left(M_{\text {age }}=25\right)$ and with 1 to 10 years of teaching experience. The participants were asked to fill out three questionnaires: the RT questionnaire by Akbari, Behzadpour, and Dadvand (2010), the questionnaire of UMS by Cheng and Dörnyei (2007), and the questionnaire of SE by Tschannen-Moran and Woolfolk Hoy (2001). Analyzing the data through running the non-parametric Spearman's rank order coefficient of correlation indicated that there was a significant and positive correlation between RT and UMS, RT and SE, and between UMS and SE. Furthermore, running a multiple regression analysis revealed that RT could more significantly predict the SE among EFL teachers. Regarding the limitations and drawing upon the findings, the article concludes with some pedagogical implications and some avenues for future research.
\end{abstract}

Index Terms - reflective teaching, sense of efficacy, use of motivational strategies

\section{INTRODUCTION}

New pedagogical trends in the field of English Language Teaching (ELT) have been paying increasing attention to the active, effective, and enabling role of ELT practitioners in teaching contexts (Akbari, Kiany, Imani Naeeni, \& Karimi Allvar, 2008; Nosratinia \& Zaker, 2014, 2017). Although numerous factors can influence the effectiveness of ELT practice, teachers' Sense of Efficacy (SE) is believed to be a major factor which can positively affect teaching behaviors and students' Second Language (L2) learning (Henson, Kogan, \& Vacha-Hassa, 2001; Tschannen-Moran \& Woolfolk Hoy, 2001).

SE, initially proposed by Bandura (1994), has been described as "belief in one's capabilities to organize and execute the courses of action required to produce given levels of attainments" (Bandura, 1997, p. 3). SE is supposed to "determine how much effort people will expand on an activity, how long they will preserve when confronting obstacles, and how resilient they will prove in the face of adverse situations" (Pajares, 1996, p. 544). Considering that in ELT contexts, teachers' autonomy, effort, and resilience have always been among desirable characteristics (Nosratinia \& Zaker, 2017), it is no wonder to observe that SE is considered an asset to ELT teachers (Brouwers \& Tomic, 2003).

English as a Foreign Language (EFL) teachers' SE has been defined as "teacher's belief that he or she has the skills necessary to effect positive change in student learning" (Distad \& Brownstein, 2004, p. 7). According to Brouwers and Tomic (2003), teachers with high SE are more open to new ideas, more willing to accept innovations, are less likely to experience burnout, support pupils' autonomy to a greater extent, and are more attentive to low ability students; they are also more confident, reveal greater enthusiasm for teaching, have greater loyalty for teaching, and are more likely to stay in the teaching profession (Tschannen-Moran \& Woolfolk Hoy, 2001). Moreover, EFL teachers' SE can contribute to EFL learners' SE (Bandura, 1995). On the other hand, it has been stated that teachers with low level of SE have poor teaching and have less effort in dealing with challenges (Tschannen-Moran \& Woolfolk Hoy, 2001).

According to Akbari and Moradkhani (2009), there is a direct relationship between EFL teachers' SE and their years of teaching experience. That is, SE would naturally develop over time. However, in order to enhance the effectiveness of ELT teacher education programs, it is essential to look for methods and techniques for developing novice and prospective teachers' SE. Research has shown that human behaviors (including those of EFL teachers) are highly affected by their internal, cognitive, metacognitive, and personality factors which in many cases interact with each other (Fahim \& Zaker, 2014; Nosratinia, Zaker, \& Saveiy, 2015; Zaker, 2015, 2016a). Consequently, it is legitimate to inspect the way SE is associated with EFL teachers' internal factors and teaching behaviors as a means for developing their SE.

Reflective Teaching (RT) is a major mental construct, reflected through teachers' teaching practice, which according to Calderhead and Gates (1993) and Dellinger, Bobbett, Dianne, and Chad (2008), can significantly develop EFL 
teachers' SE. RT is also believed to exert a positive impact on EFL learners' language proficiency (Akbari et al., 2008; Nosratinia \& Zaker, 2017). Dewey (1933, as cited in Akbari et al., 2008) postulates that reflection is "active, persistent, and careful consideration of any belief or supposed form of knowledge in the light of the grounds that support it and the further conclusion to which it tends" (p. 9).

RT is "an approach to second language classroom instruction in which current and prospective teachers collect data about teaching, examine their attitudes, beliefs, assumptions, and teaching practices, and use the information obtained as a basis for critical reflection" (Richards \& Lockart,1994, as cited in Murphy, 2001, p. 500). It is a widely-held belief that if EFL teachers do not reflect on their teaching practice, they are bound to become slaves to routine (Nosratinia \& Zaker, 2017). Akbari (2007) postulates that "teachers have always been reflecting on what they have been doing in their classes"... and it is "impossible to imagine a context in which we have human interaction on a cognitive level and no reflection going on" (p. 9). However, RT, as defined in the ELT domain, has some principles and practical guidelines (Calderhead \& Gates, 1993) which, if implemented, can function as an assisting tool for EFL teachers.

Motivating EFL learners, using Motivational Strategies (MS), in other words Use of Motivational Strategies (UMS), is believed to be another influential factor in ELT practice (Cheng \& Dörnyei, 2007), and language teachers are believed to play the most determining role in developing L2 learners' motivation (Dörnyei, 1994; Tanaka, 2005). Motivation "includes the attitudes and affective states that affect the degree of learners' effort to learn an L2" (Ellis, 1997, p. 75). Some have argued that motivation is the biggest single factor affecting L2 learners' success (Harmer, 2001). In an ELT context, MS refer to techniques teachers implement in order to promote and maintain learners' motivation to learn (Dörnyei, 2001; Dörnyei \& Guilloteaux, 2008).

As stated above, a myriad of studies have assumed significant roles for RT (e.g. Dellinger et al., 2008) and UMS (Cheng \& Dörnyei, 2007) in developing ELT practitioners' teaching practice and SE. However, the systematic comparison between RT and UMS in predicting SE as well as the systematic inspection of the way these three variables are associated are the areas which have not been touched in the ELT domain so far. Such an attempt would enhance our level of understanding of these mental constructs. Furthermore, this comparison would enable teacher educators to come up with more appropriate decisions when attempting to enhance novice teachers' SE. Motivated by these premises, the researchers formulated the following research questions:

Research Question 1: Is there any significant relationship between EFL teachers' reflective teaching and use of motivational strategies?

Research Question 2: Is there any significant relationship between EFL teachers' reflective teaching and sense of efficacy?

Research Question 3: Is there any significant relationship between EFL teachers' use of motivational strategies and sense of efficacy?

Research Question 4: Is there any significant difference between EFL teachers' reflective teaching and use of motivational strategies in predicting their sense of efficacy?

\section{METHOD}

\section{Participants}

The individuals taking part in this study were 194 male and female (56 males and 138 females) EFL teachers within the age range of 20 to $30\left(M_{\text {age }}=25\right)$ and with 1 to 10 years of teaching experience. These participants were studying ELT, English Translation, and English Literature at Islamic Azad University at Central Tehran and Payame-Noor University, Tehran. They were selected based on convenient non-random sampling. It should be noted that the initial number of participants was 206; however, 12 individuals were excluded due to providing careless and incomplete answers.

\section{Instrumentation}

In order to fulfill the purpose of the study, the following instruments were utilized:

1. English Language Teaching Reflection Inventory developed by Akbari, Behzadpour, and Dadvand (2010);

2. Motivational Strategies Questionnaire developed by Cheng and Dörnyei (2007); and

3. Teachers' Sense of Self Efficacy Scale developed by Tschannen-Moran and Woolfolk Hoy (2001).

\section{English Language Reflection Inventory Questionnaire}

The English Language Reflection Inventory Questionnaire was developed by Akbari et al. (2010). The questionnaire covers six different components of reflective teaching, namely Practical Element, Cognitive Element, Learner Element (affective), Metacognitive Element, Critical Element, and Moral Element. The questionnaire includes 29 items on a 5 point Likert-scale format ranging from never (1 point), seldom ( 2 points), sometimes ( 3 points), often (4 points), and always (5 points). The instrument reportedly enjoys high reliability and validity (Akbari et al., 2010; Yesilbursa, 2013). The allocated time for answering the questionnaire is 15 minutes and the scores of the questionnaire range from 29 to 145. The reliability of RT questionnaire in this study was estimated to be 0.70 using the Cronbach's alpha coefficient.

Motivational Strategies Questionnaire

The Motivational Strategies Questionnaire was developed by Cheng and Dörnyei (2007). It consists of ten macro strategies namely Proper Teacher Behavior, Recognize Students' Effort, Promote Learners' Self-Confidence, Creating a Pleasant Classroom Climate, Present Tasks Properly, Increase Learners' Goal-Orientedness, Make the Learning Tasks 
Stimulating, Familiarize Learners with L2-Related Values, Promote Group Cohesiveness and Group Norms, and Promote Learner Autonomy. The questionnaire contains 48 items. Responses to the individual items are scored on a scale ranging from 1 to 6 , hardly ever to very often. The participants were allocated 30 minutes to complete the questionnaire. The ultimate score was computed in the possible range of 48 to 288 . The reliability of the UMS questionnaire in this study was estimated to be 0.71 using the Cronbach's alpha coefficient.

\section{Teachers' Sense of Self Efficacy Scale}

The Teachers' Sense of Efficacy Scale was developed and validated by Tschannen-Moran and Woolfolk Hoy (2001) to measure SE beliefs of teachers. This scale consists of three components, namely Efficacy for Instructional Strategies, Efficacy for Students' Engagement, and Efficacy for Classroom Management. Each component is assessed by 8 items. Therefore, the scale is composed of 24 items on 9 point Likert-scale from 1 to 9, ranging from Nothing to Great Deal. The allocated time for answering the questionnaire is 15 minutes and the possible range of participants' scores is from 24 to 216 . The reliability of this scale in this study was estimated to be 0.68 using the Cronbach's alpha coefficient.

\section{Procedure}

In order to achieve the purpose of this study, the researchers followed certain steps, stated in a chronological order in this section. After obtaining a formal approval for conducting this research in the universities mentioned above (see participants), fourteen classes were selected. All the three questionnaires were distributed in one package. Before administering the packages, the researchers deliberately randomized the order of the questionnaires in every package in order to curb the influence of order on the answering process. The required explanations were given to the participants, and the participants were informed about the aim of the study. Also, the researchers informed the participants that the collected data would be confidentially employed for answering the questions of this research.

Afterwards, the packages were administered to 206 individuals. The allocated time for answering the three questionnaires was 60 minutes. The researchers monitored the filling out process randomly in order to ensure that the participants were able to totally understand the questions and responses. After 1 hour, the questionnaires, now answered, were collected, and they were scored. From the initial 206 sets of administered questionnaires, a number of 194 sets were completed carefully. The data obtained from these 194 sets were employed for carrying out the statistical analyses.

\section{RESULTS}

\section{Preliminary Analyses}

Prior to answering the research questions of the study, it was essential to examine a number of assumptions and carry out some initial analyses. Initially, the assumptions of interval data and independence of subjects/participants (Tabachnick \& Fidell, 2007) were already met since the data scale was interval and the participants were independent of one another. Furthermore, some other significant assumptions had to be checked. These assumptions, as stated by Tabachnick and Fidell (2007), are:

1. Linear relation between each pair of variables,

2. Homoscedasticity, and

3. Normality of the distribution of variables.

In order to inspect the linearity of relations, the researchers created a multiple scatterplot which confirmed the linearity of relations (Figure 1). Moreover, the distribution of scores was not funnel shape, i.e. wide at one end and narrow at the other; therefore, the assumption of homoscedasticity was met for these variables.

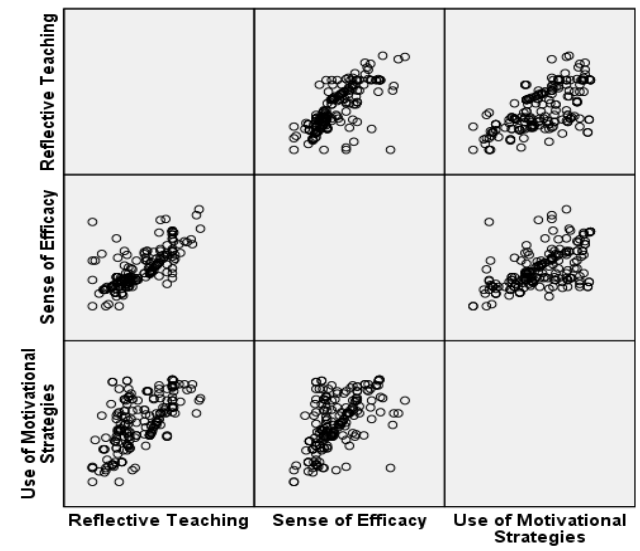

Figure 1: Multiple scatterplot of reflective teaching, sense of efficacy, and use of motivational strategies

For checking the normality of the distributions, first, the descriptive statistics of the data were obtained and kurtosis and skewness ratios were calculated. The obtained results indicated that the distributions of the scores were not normal as one skewness ratio value and two kurtosis ratio values did not fall within the range of -1.96 and +1.96 . Second, the Kolmogorov-Smirnov test was run, results of which are presented in Table 1. 
TABLE 1:

TESTS OF NORMALITY OF THE SCORES

\begin{tabular}{lllllll}
\hline & \multicolumn{7}{l}{ Kolmogorov-Smirnov } & & Shapiro-Wilk \\
\cline { 2 - 7 } & Statistic & Df & Sig. & Statistic & df & Sig. \\
\hline Reflective Teaching & .138 & 194 & .000 & .964 & 194 & .000 \\
Sense of Efficacy & .141 & 194 & .000 & .948 & 194 & .000 \\
Use of Motivational Strategies & .073 & 194 & .014 & .972 & 194 & .001 \\
\hline a. Lilliefors Significance Correction & & & &
\end{tabular}

As presented in Table 1, all the Sig. values for the scores of the three variables of the study are lower than the critical value (.05). Therefore, it was concluded that the assumption of normality of distribution is violated (Tabachnick \& Fidell, 2007). Considering the results reported so far, it was systematically suggested that the assumption of normality is violated for the scores of RT, SE, and UMS. Therefore, the research questions were answered through employing nonparametric tests.

\section{The First Research Question}

The first motivating force behind conducting this study was to systematically inspect the relationship between EFL teachers' RT and UMS. To do so, the data were analyzed using the Spearman rank order coefficient of correlation (Table 2).

TABLE 2:

SPEARMAN's CORRELATION BETWEEN REFLECTIVE TEACHING AND USE OF MOTIVATIONAL STRATEGIES

\begin{tabular}{|c|c|c|c|c|}
\hline & & & Reflective Teaching & $\begin{array}{l}\text { Use of Motivational } \\
\text { Strategies }\end{array}$ \\
\hline \multirow[t]{6}{*}{ Spearman's rho } & Reflective Teaching & Correlation Coefficient & 1.000 & $.623^{3 * 6}$ \\
\hline & & Sig. (2-tailed) & . & .000 \\
\hline & & $\mathrm{N}$ & 194 & 194 \\
\hline & Use of Motivational Strategies & Correlation Coefficient & $.623^{* * *}$ & 1.000 \\
\hline & & Sig. (2-tailed) & .000 & . \\
\hline & & $\mathrm{N}$ & 194 & 194 \\
\hline
\end{tabular}

**. Correlation is significant at the 0.01 level (2-tailed).

According to the results of the analysis reported in Table 2, it was concluded that there was a significant and positive correlation between RT and UMS, $\rho=.623, n=194, p<.01$. According to Cohen (1988), this signified a large effect size (99\% confidence intervals: $0.496-0.724)$.

\section{The Second Research Question}

The second intention of this study was to systematically investigate the relationship between EFL teachers' RT and SE. In order to answer this question, the data were analyzed using the Spearman rank order coefficient of correlation (Table 3).

TABLE 3:

SPEARMAN'S CORRELATION BETWEEN REFLECTIVE TEACHING AND SENSE OF EFFICACY

\begin{tabular}{|c|c|c|c|c|}
\hline & & & Reflective Teaching & Sense of Efficacy \\
\hline \multirow[t]{4}{*}{ Spearman's rho } & Reflective Teaching & Correlation Coefficient & 1.000 & $.763^{* *}$ \\
\hline & & Sig. (2-tailed) & . & .000 \\
\hline & Sense of Efficacy & Correlation Coefficient & $.763^{* *}$ & 1.000 \\
\hline & & Sig. (2-tailed) & .000 & . \\
\hline
\end{tabular}

According to the results of the analysis reported in Table 3, it was concluded that there was a significant and positive correlation between RT and SE, $\rho=.763, n=194, p<.01$, signifying a large effect size (99\% confidence intervals: $0.674-0.83)$.

\section{The Third Research Question}

The third intention of this study was to systematically investigate the relationship between EFL teachers' UMS and SE. In order to answer this question, the data were analyzed using the Spearman rank order coefficient of correlation (Table 4). 
TABLE 4:

SPEARMAN's CORRELATION BETWEEN USE OF MOTIVATIONAL STRATEGIES AND SENSE OF EFFICACY

\begin{tabular}{|c|c|c|c|c|}
\hline & & & $\begin{array}{l}\text { Use of Motivational } \\
\text { Strategies }\end{array}$ & Sense of Efficacy \\
\hline \multirow[t]{6}{*}{ Spearman's rho } & \multirow[t]{3}{*}{ Use of Motivational Strategies } & Correlation Coefficient & 1.000 & $.567^{* * 1}$ \\
\hline & & Sig. (2-tailed) & . & .000 \\
\hline & & $\mathrm{N}$ & 194 & 194 \\
\hline & \multirow[t]{3}{*}{ Sense of Efficacy } & Correlation Coefficient & $.567^{* *}$ & 1.000 \\
\hline & & Sig. (2-tailed) & .000 & . \\
\hline & & $\mathrm{N}$ & 194 & 194 \\
\hline
\end{tabular}

**. Correlation is significant at the 0.01 level (2-tailed).

According to the results of the analysis reported in Table 4, it was concluded that there was a significant and positive correlation between UMS and SE, $\rho=.567, n=194, p<.01$, signifying a large effect size (99\% confidence intervals: $0.428-0.68$ ).

Based on the findings stated above, both RT and UMS were significantly related to SE. As a result, the researchers could consider answering the fourth research question, considering RT and UMS the predictor variables of the predicted variable, SE.

\section{Preliminary Analyses Pertinent to the Fourth Research Question}

In order to answer the fourth research question, a multiple regression analysis was run. However, a number of assumptions had to be checked prior to performing the analysis. According to Tabachnick and Fidell (2007), these assumptions are:

1. Sample size

2. Multicollinearity

3. Normality

4. Outliers

According to Tabachnick and Fidell's (2007) formula, the sample in such a study should include more than 66 participants. Including 194 cases, the sample pool seemed to be large enough to meet this assumption. In order to inspect the possibility of multicollinearity, the Tolerance and VIF values were obtained (Table 5). Both of the Tolerance values were higher than .1, and the VIF values were lower than 10 . Therefore, it was concluded that multicollinearity did not exist in this sample.

TABLE 5:

TOLERANCE AND VIF VALUES

\begin{tabular}{llll}
\hline \multirow{2}{*}{ Model } & & \multicolumn{2}{l}{ Collinearity Statistics } \\
\cline { 3 - 4 } & & Tolerance & VIF \\
\hline 1 & (Constant) & .600 & 1.667 \\
& Reflective Teaching & .600 & 1.667 \\
& Use of Motivational Strategies & .600
\end{tabular}

Next, for checking the normality, the Normal Probability Plot (P-P) was inspected. (Figure 2), suggesting no major deviation from normality.

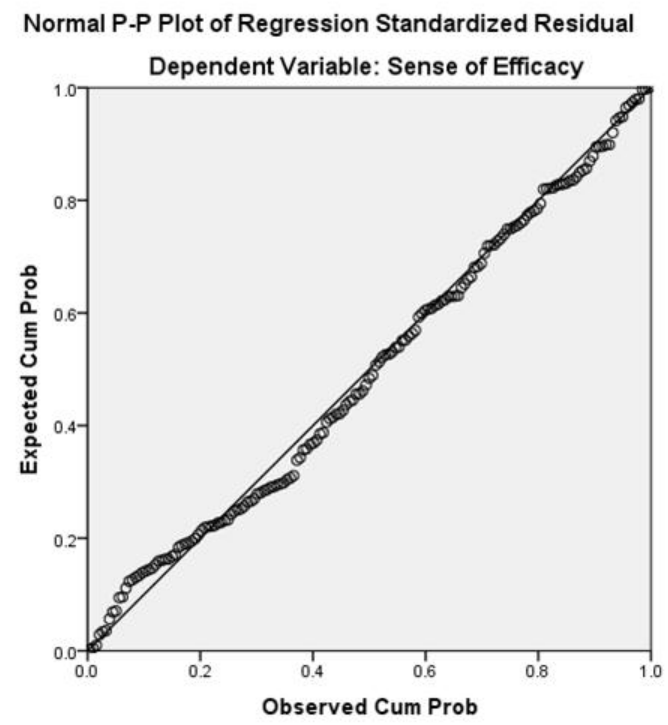

Figure 2: The normal P-P plot of regression standardized residual 
Finally, in order to check the presence of outliers, the researchers inspected the Mahalanobis distance value (Table 6).

TABLE 6:

RESIDUALS STATISTICS

\begin{tabular}{llllll}
\hline & Minimum & Maximum & Mean & Std. Deviation & N \\
\hline Mahal. Distance & .036 & 10.077 & 1.990 & 1.713 & 194 \\
Cook's Distance & .000 & .331 & .007 & .026 & 194 \\
\hline a. Dependent Variable: Sense of Efficacy & & & &
\end{tabular}

Table 6 reported that the highest Mahalanobis value in this sample is 10.077 which is way below the critical level (13.28). Also, Cook's Distance values were desirably smaller than the critical value 1. As a result, the researchers could argue that the assumption pertinent to the outliers is met. Based on the results of the abovementioned preliminary analyses, it was proper to run a multiple regression for answering the fourth research question.

\section{The Fourth Research Question}

In order to answer this question, a standard multiple regression was run. In this analysis, RT and UMS were the predictor variables, and SE was the predicted variable. Table 7 presents the regression model summary including the $R$ and $R^{2}$.

TABLE 7:

MODEL SUMMARY - R AND R SQUARE

\begin{tabular}{lcccc}
\hline Model & $\mathrm{R}$ & $\mathrm{R}$ Square & Adjusted R Square & Std. Error of the Estimate \\
\hline 1 & $.743^{\mathrm{a}}$ & .553 & .548 & 13.383 \\
\hline $\begin{array}{l}\text { a. Predictors: (Constant), Use of Motivational Strategies, Reflective Teaching } \\
\text { b. Dependent Variable: Sense of Efficacy }\end{array}$
\end{tabular}

As reported in Table 7, $R$ was 0.743 and $R^{2}$ was 0.553 . This indicates that the model explains 55.3 percent of the variance in SE (Cohen, Cohen, West, \& Aiken, 2003). Moreover, $f^{2}=1.237$ indicated a large effect size for the regression. Table 8 reports the results of ANOVA $(F(2,191)=118.007, p=0.0005)$, the results of which were considered significant. This means that the model can significantly predict EFL teachers' SE.

TABLE 8:

REGRESSION OUTPUT: ANOVA

\begin{tabular}{|c|c|c|c|c|c|c|}
\hline Model & & Sum of Squares & Df & Mean Square & $\mathrm{F}$ & Sig. \\
\hline \multirow[t]{3}{*}{1} & Regression & 42270.194 & 2 & 21135.097 & 118.007 & $.000^{\mathrm{a}}$ \\
\hline & Residual & 34208.059 & 191 & 179.100 & & \\
\hline & Total & 76478.253 & 193 & & & \\
\hline
\end{tabular}

b. Dependent Variable: Sense of Efficacy

Table 9 demonstrates the Standardized Beta Coefficients. Inspecting of the Sig. values indicated that both RT and UMS make statistically significant unique contributions to the equation as their Sig. values are less than .05.

TABLE 9:

REGRESSION OUTPUT: COEFFICIENTS

\begin{tabular}{|c|c|c|c|c|c|c|}
\hline \multirow[b]{2}{*}{ Model } & \multicolumn{2}{|c|}{ Unstandardized Coefficients } & \multirow{2}{*}{$\begin{array}{l}\text { Standardized } \\
\text { Coefficients } \\
\beta \beta\end{array}$} & \multirow[b]{2}{*}{$\mathrm{T}$} & \multirow[b]{2}{*}{ Significance } & \multirow[b]{2}{*}{ Part Correlation } \\
\hline & $\mathrm{B}$ & SE & & & & \\
\hline $1 \quad$ (Constant) & 51.838 & 10.333 & & 5.017 & .000 & \\
\hline Reflective Teaching & .695 & .067 & .645 & 10.320 & .000 & .499 \\
\hline Use of Motivational Strategies & .129 & .057 & .143 & 2.285 & .023 & .111 \\
\hline
\end{tabular}

The comparison of $\beta$ values revealed that RT has the largest $\beta$ coefficient $(\beta=0.645, t=10.32, p=0.0005)$, meaning that it makes the strongest statistically significant unique contribution to explaining SE. Consequently, it was deduced that RT could more significantly predict the SE scores of the participants. Moreover, UMS was ranked as the second predictor of SE. Finally, the inspection of Part correlation revealed that RT uniquely explains 24.9 percent of the variance in SE $(.499 \times .499=.249)$.

\section{DISCUSSION}

In recent years, the ELT pedagogy has been becoming increasingly conscious of the significance of teachers' role in materializing pedagogical goals (Akbari et al., 2008; Nosratinia \& Zaker, 2017). Consequently, and quite reasonably, there has been a penchant for indicating those factors which have the highest contribution to ELT practitioners' success and learners' language learning (Nosratinia \& Zaker, 2017). Among these factors, SE is believed, unanimously, to be a key asset to ELT teachers (Henson et al., 2001).

Rooted in the abovementioned premise, it seemed reasonable to inspect the way SE is associated with EFL teachers' 
internal factors and teaching behaviors as a means for developing their SE. Consequently, the present study attempted to inspect the way EFL teachers' RT and UMS interact with their SE. The literature abounds with studies which assume a major role for RT (Dellinger et al., 2008; Nosratinia \& Zaker, 2017) and UMS (Cheng \& Dörnyei, 2007) in determining EFL teachers' pedagogical triumph and SE directly and indirectly. However, the systematic comparison between RT and UMS in predicting SE as well as the systematic inspection of the way these three variables are associated are among areas which had not been touched before this study.

This descriptive study considered RT and UMS the predictor variables and SE the predicted variable. As it was systematically suggested that the assumption of normality is violated for the scores of RT, SE, and UMS, the formulated research questions (see Introduction) were answered through employing non-parametric tests. Answering the first research question indicated that there was a significant and positive correlation between RT and UMS. As stated earlier, these two variables, or teaching behaviors, are both crucial to ELT practitioners' success and SE. The observed significant correlation is evidence that RT and UMS share some features and underlying factors, making both of them effective in developing the pedagogical practice. This implies that the assumption of the relevance of variables, needed for the prediction question (see Research Question 4) is met (Best \& Kahn, 2006).

A further driving force of this study was inspecting the association between RT and SE. Numerous studies have suggested that these two mental constructs interact with each other (Akbari, 2007; Lowery, 2003). Answering the second research question indicated that RT and SE are significantly correlated. This is to say that high levels of RT result in observing high levels of SE, and vice versa. This result confirmed the results of two other studies, focusing on the association between RT and SE (Moradian \& Ahmadi, 2014; Noormohammadi, 2014). This confirmation, according to the principles of meta-analysis (Best \& Kahn, 2006), suggests that there is a causal relationship between RT and SE, making it more and more legitimate for EFL teacher education programs to invest in developing EFL teachers' RT as a means for developing their SE and success.

The third research question focused on the way UMS and SE are associated. UMS, according to many ELT scholars, is highly influential in ELT practice (Cheng \& Dörnyei, 2007), and it can directly and indirectly contribute to teachers' success and SE (Harmer, 2001). The existence of such a significant relationship was confirmed through answering the third research question. As a result, systematic support is provided for the notion that UMS can enhance the level of SE among EFL teachers. This point seems to have pedagogical implications for teacher training programs, stated in the next section.

As stated above, both RT and UMS were significantly related to SE. Put another way, both RT and UMS can predict EFL teachers' SE. However, comparing their predictive power was something which the researchers dealt with while answering the fourth research question. Results indicated that RT makes the strongest statistically significant unique contribution to explaining EFL teachers' SE. This is to say that, compared to UMS, RT is a better predictor of EFL teachers' SE. This finding highlights the importance of RT in teacher education programs even further. The last point to be made is that participants' internal factors, which are highly diverse and influential (Zaker, 2016b), along with other features of the context and participants can influence the findings of studies in the ELT domain (Best \& Kahn, 2006; Tabachnick \& Fidell, 2007); this suggests that the advantage of RT over UMS in predicting EFL teachers' SE should be checked and confirmed in other ELT contexts.

\section{CONCLUSION}

The present study aimed at systematically investigating the association among EFL teachers' RT, UMS, and SE. ELT teachers' SE is now believed to be a major factor in promoting L2 learning (Henson et al., 2001; Tschannen-Moran \& Woolfolk Hoy, 2001), making it an asset to ELT teachers (Brouwers \& Tomic, 2003). Using a descriptive design, this study attempted to inspect the way SE is associated with two other major pedagogical behaviors, RT and UMS.

As stated earlier, the literature abounds with studies which assume a major role for RT (Dellinger et al., 2008; Nosratinia \& Zaker, 2017) and UMS (Cheng \& Dörnyei, 2007) in determining EFL teachers' pedagogical triumph and SE directly and indirectly. The obtained results indicated that SE, RT, and UMS are significantly associated. Moreover, it was concluded that RT is a better predictor of SE, when compared with UMS. Basically, the findings provided support for the widely held belief that reflective practice in ELT contexts develops teachers' behavior and triggers positive change (Farrell, 2003). However, it is important to consider that UMS and the way it influences the pedagogical practice is context-bound and highly affected by culture (Cheng \& Dörnyei, 2007). As a result, the advantage of RT over UMS regarding predicting SE needs to be checked in other contexts with different cultures.

All in all, based on the obtained results and considering the limitations and peculiarities of this study, the researchers came up with the following conclusions:

a) EFL teachers can develop their SE if they attempt to implement RT and UMS

b) RT and UMS share some underlying components.

c) Between RT and UMS, the former has a higher level of pedagogical advantage for developing the ELT practice.

The key implication of the findings of the present study concerns the EFL teachers. The findings of this study provide reasonable support for suggesting that EFL teachers should invest in developing their knowledge of RT. They should also delve into the models of RT and enhance their familiarity with the ways using which they can function as reflective teachers. According to Dewey (1933), the key attitudes essential for engaging in a reflective teaching practice 
are:

1) Open-mindedness,

2) Responsibility, and

3) Wholeheartedness.

Implementing these key factors, EFL teachers should function as reflective practitioners and evaluate their teaching practice. More specifically, EFL teachers should "collect data about their teaching, examine their attitudes, beliefs, assumptions, and teaching practices, and use the information obtained as a basis for critical reflection about teaching" (Farrell, 2008, p. 2). They should also attempt to enhance their familiarity with different teaching methods and, implementing a reflective and critical vision, and inspect their practicality in different teaching contexts (Philips, 2007).

In addition to the focus on a reflective practice, EFL teachers are also suggested to implement MS through which they can develop their performance and SE. Needless to say, EFL teachers should observe the different motivational techniques available in the literature; however, when it comes to implementing these MS, they should consider the cultural suitability and relevance of the techniques, which, as stated earlier, can determine how these strategies affect learning. In implementing MS, EFL teachers are suggested to (Oxford \& Shearin, 1994):

a) spot learners' actual reasons for L2 learning;

b) assist learners in setting challenging yet realistic goals;

c) inform the learners about the advantages of L2 learning;

d) provide a secure, friendly, and non-threatening environment; and

e) motivate learners to develop high but realistic intrinsic motivation.

Teacher education programs should attempt to familiarize the prospective teachers with the components of RT so that the teachers are enabled to function in a more pedagogically appropriate way in EFL classrooms (Ferguson, 1998; Goldhaber, 2002; Sanders, 2000). In addition, EFL syllabus designers are encouraged to prepare EFL materials in a way that EFL teachers are encouraged to implement RT and modify the classroom procedure whenever needed. Furthermore, EFL syllabi should familiarize the teachers with MS and highlight the significance of motivating the learners when offering pedagogical suggestions and guidelines.

Considering the peculiarities of the present study, there are some possible avenues for future research. First, this study was conducted among EFL teachers having 1 to 10 years of teaching experience; therefore, the same study could be conducted among more experienced teachers. Second, it is suggested to replicate this study in a way that the numbers of male and female participants are equal so that gender might not function as an intervening variable. Third, this study can be replicated while implementing some qualitative data collection measures in order to enhance the validity and reliability of the obtained results and pertinent interpretations. Finally, other researchers are recommended to employ pure/simple random sampling while replicating this study in order to enhance the validity of the findings.

\section{REFERENCES}

[1] Akbari, R. (2007). Reflections on reflection: A critical appraisal of reflective practices in L2 teacher education. System, 35(2), 192-207.

[2] Akbari, R., Kiany, G. R., Imani Naeeni, M., \& Karimi Allvar, N. (2008). Teachers' teaching styles, sense of efficacy and reflectivity as correlates of students' achievement outcomes. The Electronic Journal for English as a Second Language, 11, 122.

[3] Akbari, R., \& Moradkhani S. (2009). Iranian English teachers' self-efficacy: Do academic degree and experience make a difference? Pazhuhesh-e Zabanha-ye Khareji, 56, 25-47.

[4] Bandura, A. (1994). Self-efficacy. In V. S. Ramachaudran (Ed.), Encyclopedia of human behavior (vol. 4, pp. 71-81). New York: Academic Press.

[5] Bandura, A. (1995). Self-efficacy in changing societies. New York: Cambridge University Press.

[6] Bandura, A. (1997). Self-efficacy: The exercise of control. New York: Freeman.

[7] Best, J. W., \& Kahn, J. V. (2006). Research in education (10th ed.). Boston, MA: Pearson Education, Inc.

[8] Brouwers, A., \& Tomic, W. (2003). A test of the factorial validity of the teacher efficacy scale. Research in Education, 69, 6780.

[9] Calderhead, J., \& Gates, P. (Eds.). (1993). Conceptualizing reflection in teacher development. Lewes: Flamer Press.

[10] Cheng, H. F., \& Dörnyei, Z. (2007). The use of motivational strategies in language instruction: The case of EFL teaching in Taiwan. Innovation in Language Learning and Teaching 1(1), 153-174.

[11] Cohen, J. W. (1988). Statistical power analysis for the behavioral sciences (2nd ed.). Hillsdale, NJ: Lawrence Erlbaum Associates.

[12] Cohen, J., Cohen, P., West, S. G., \& Aiken, L. S. (2003). Applied multiple regression/correlation analysis for the behavioral sciences (3rd ed.). NJ: Lawrence Erlbaum Associates.

[13] Dellinger, A., Bobbett, J., Dianne, F. O., \& Chad, O. (2008). Measuring teachers' self-efficacy beliefs: Development and use of the TEBS-Self. Teaching and Teacher Education, 24, 751-766.

[14] Dewey, J., (1933). How we think: A re-statement of the relation of reflective thinking to the education process. DC. Heath, \& Co., Boston.

[15] Distad, L., \& Brownstein, J. (2004). Talking teaching: Implementing reflective practice in groups. United Kingdom: Scarecrow Education.

[16] Dörnyei, Z. (1994). Motivation and motivating in the foreign language classroom. Modern Language Journal, 78, $273-284$.

[17] Dörnyei, Z. (2001). Motivational strategies in the language classroom. Cambridge, Cambridge University Press. 
[18] Dörnyei, Z. (2007). Creating a motivating classroom environment. In J. Cummins \& C. Davidson, (Eds.), International Handbook of English Language Teaching (Vol. 2; pp. 219-231). New York, NY: Springer.

[19] Dörnyei, Z., \& Guilloteaux, M. J. (2008). Motivating language learners: A classroom-oriented investigation of the effects of motivational strategies on student motivation. TESOL Quarterly, 42, 55-77.

[20] Ellis, R. (1997). Second language acquisition. Oxford: Oxford University Press.

[21] Fahim, M. \& Zaker, A. (2014). EFL learners' creativity and critical thinking: Are they associated? Humanising Language Teaching, 16(3). Retrieved October 2, 2015, from http://www.hltmag.co.uk/jun14/mart01.htm.

[22] Farrell, T. (2003). Reflective teaching: Principles and practice. English Teaching Forum, 41(4), 14-21.

[23] Farrell, T. (2008). Reflective language teaching: From research to practice. New York: Continuum.

[24] Ferguson, R. (1998). Teachers' Perceptions and the Black-White Test Score Gap. In C. Jencks \& M. Phillips (Eds.), The BlackWhite Test Score Gap (pp. 273-317). Washington, DC: Brookings Institution Press.

[25] Goldhaber, D. (2002). The mystery of good teaching: Surveying the evidence on student achievement and teachers' characteristics. Education Next, 2(1), 50-55.

[26] Harmer, J. (2001). The practice of English language teaching (3rd ed.). Edinburgh: Pearson Education Limited.

[27] Henson, R. K., Kogan, L. R., \& Vacha-Haase, T. (2001). A reliability generalization study of the teacher efficacy scale and related instruments. Educational and psychological Measurement, 61(3), 404-420.

[28] Lowery, N. V. (2003). The fourth "R": Reflection. The Mathematics Educator, 13(2), 23-31.

[29] Moradian, M. R., \& Ahmadi, N. (2014). The relationship between reflectivity in teaching and the sense of self-efficacy among novice and experienced Iranian EFL teachers. Paper presented at the Second National Applied Research Conference on English Language Studies, Tehran, Iran.

[30] Murphy, J. b. M. (2001). Reflective teaching in ELT. In M. Celce Murcia, (Ed.). Teaching English as a Second or Foreign Language (p. 499-514). Boston: Heinle \& Heinle.

[31] Noormohammadi, S. (2014). Teacher reflection and its relation to teacher efficacy and autonomy. Social and Behavioral Science, 98, 1380-1389.

[32] Nosratinia, M., \& Zaker, A. (2014). Metacognitive attributes and liberated progress: The association among second language learners' critical thinking, creativity, and autonomy. SAGE Open 4.3, 1-10. doi: 10.1177/2158244014547178.

[33] Nosratinia, M., \& Zaker, A. (2017). Scrutinizing the impact of teachers' critical thinking and teaching autonomy on their teaching success and learners' use of language learning strategies. Journal of Language Teaching and Research, 8(1), 1-16.

[34] Nosratinia, M., Zaker, A. \& Saveiy, M. (2015). Higher-order thinking and individualized learning: Metacognitive awareness and self-efficacy among EFL learners. The Iranian EFL Journal 11.1, 189-207.

[35] Oxford, R. L., \& Shearin, J. (1994). Language learning motivation: Expanding the theoretical framework. Modern Language Journal, 78, 12-28.

[36] Pajares, F. (1996). Self-efficacy beliefs in academic settings. Review of Educational Research, 66(4), 543-587.

[37] Philips, R. (2007). Reflective teaching of history. New York: SAGE Publication.

[38] Richards, J. C., \& Lockhart, C. (1994). Reflective teaching in second language classrooms. Cambridge: Cambridge University Press.

[39] Ross, D. (1990). Programmatic structures for the preparation of reflective teachers. In R. Clift, W. R. Houston, \& M. Pugach (Eds.), Encouraging Reflective Practice in Education (pp. 97-118). New York: Teachers College Press.

[40] Sanders, W. L. (2000). Value-added assessment from student achievement data. Cary, NC: Create National Evaluation Institute.

[41] Tabachnick, B. G., \& Fidell, L. S. (2007). Using multivariate statistics. Boston, MA: Pearson Education, Inc.

[42] Tanaka, T. (2005). Teacher influence on learner motivation. Osaka Female Junior College, System, 37, 57-69.

[43] Tschannen-Moran, M., \& Woolfolk Hoy, A. (2001). Teacher efficacy: Capturing an elusive construct. Teaching and Teacher Education, 17, 783-805.

[44] Yesilbursa, A. (2013). Construct validation of the English language teaching reflective inventory with a sample of Turkish university EFL instructors. English Language Teaching Journal, 6(5), 28-37.

[45] Zaker, A. (2015). EFL learners' language learning strategies and autonomous learning: Which one is a better predictor of L2 skills? Journal of Applied Linguistics-Dubai 1.1, 27-39.

[46] Zaker, A. (2016a). Literature and creativity in an ELT context. ASIAN TEFL: Journal of Language Teaching and Applied Linguistics, 1(2), 175-186.

[47] Zaker, A. (2016b). Social constructivism and metacognition in an EFL context: Inspecting the contribution of critical thinking to EFL learners' social intelligence. Humanising Language Teaching, 18(6), 1-14. Retrieved December 21, 2016, from http://www.hltmag.co.uk/dec16/mart03.htm.

Mania Nosratinia is Assistant Professor in TEFL at Islamic Azad University at Central Tehran. She has been teaching at undergraduate and graduate levels in the areas of English language teaching methodology, language testing, and research methodology in language studies. She has published in national and international academic journals and presented in several national and international seminars.

Zahra Moradi holds an MA in TEFL from Islamic Azad University at Central Tehran and is an English teacher at a number of language schools. Her main areas of research interest include reflective teaching, motivational strategies, and teacher education. 